Article

\title{
Principal Leadership Styles and Teacher Job Performance: Viewpoint of Middle Management
}

\author{
Atif Saleem $\left.{ }^{1,+} \mathbb{(}\right)$, Sarfraz Aslam ${ }^{2, *},{ }^{\dagger}$, Hong-biao Yin ${ }^{3} \mathbb{D}$ and Congman Rao ${ }^{1, *}$ \\ 1 Faculty of Education, Northeast Normal University, Changchun 130024, China; ad668@nenu.edu.cn \\ 2 School of Education, Shaanxi Normal University, Xi'an 710062, China \\ 3 Department of Curriculum and Instruction, Chinese University of Hong Kong, Hong Kong 999077, China; \\ yinhb@cuhk.edu.hk \\ * Correspondence: sarfrazmian@nenu.edu.cn (S.A.); raocm506@nenu.edu.cn (C.R.) \\ $\dagger$ Both authors contributed equally to the study.
}

Received: 21 March 2020; Accepted: 6 April 2020; Published: 21 April 2020

check for updates

\begin{abstract}
Achievement-oriented leaders let their followers know their expectations. They regularly set clear goals with potential high-performance standards, they trust in the capabilities of their subordinates, and they encourage the continued performance improvement of their subordinates. This investigation studied the effects of private secondary school principals' leadership styles on teachers' job performance. Four leadership styles outlined in the path-goal theory and five key performance indicators (KPIs) of teacher job performance were chosen for the present research. Numerous prior studies have documented this subject. However, they reported on teacher job performance as a single unit. Therefore, a concerted effort was required to examine the effects of adopted principal leadership styles on each of the five key performance indicators of teacher job performance. A total of 253 middle management personnel took part in this empirical study. The correlation findings from the structural equation modeling revealed that the directive leadership style had a significant effect on teacher job performance in the studied schools, followed by the supportive and achievement-oriented leadership styles. Conversely, although participative leadership was identified as a significant predictor, it was not considered a promising predictor of teacher job performance. This research was conducted in a non-Western culture, where directive leadership is beneficial for encouraging teacher job performance; this claim is greatly supported by the available rigorous literature.
\end{abstract}

Keywords: leadership; principal leadership styles; path-goal theory; teacher job performance

\section{Introduction}

Paradoxically, path-goal theory (PGT) is confusing due to the complexity of the theory itself, and it encompasses several heterogeneous aspects of leadership due to its broad scope and the interrelated set of assumptions about the leadership process [1]. The theory distinguishes between four leadership styles-directive, participative, supportive, and achievement-oriented-which are appropriate for standard operating procedures (SOPs), clarification of challenging goals regarding the task structure and carrying out assignments, the formal authority system, and successful job completion.

Hence, the choice of one leadership style that simultaneously incorporates all of these attributes is a daunting task in the school context. As for practical outcomes, the theory requires school leaders and principals to provide assistance, directions, and guidance to clarify job goals for teachers and remove obstacles that stop teachers from accomplishing these goals so that they can perform as expected. Furthermore, PGT incorporates expectancy theory principles, by which followers (teachers) get motivated when their efforts and performance are reasonably contributive [2]. 
However, PGT inadequately elucidates the relationship between principal leadership styles and teacher job performance, i.e., it inadequately explains the favorable role of such leadership styles in promoting teacher job performance. Thus, principals do not have a clear understanding of how their leadership informs teacher job performance. Notably, it does not provide adequate explication of the effects of the four leadership styles on various job performance subcategories in terms of the following key performance indicators (KPIs): (a) teaching planning, (b) classroom organization, (c) monitoring and evaluation, (d) classroom atmosphere and discipline, and (e) teacher leadership [3]. The following literature provides a brief overview of the effects of principal leadership styles on teacher job performance that need to be explored in detail.

\section{Literature Review}

\subsection{Path-Goal Theory and Principal Leadership}

Drawing heavily on the leadership literature, the path-goal theory (PGT) of leadership first appeared in the 1970s in the works of Evans [4], House [5], House and Dessler [6], and House et al. [7], and it was revised in the work of House [8] in 1996 [1]. The theory originally consisted of four styles of leadership (directive, participative, supportive, and achievement-oriented leadership). The overview of these leadership styles, according to Northouse [1], is as follows. Directive leaders provide task directions and instructions to their followers that incorporate what their expectations are, how to follow them, and when to complete them. Furthermore, he added that performance standards, rules, and regulations are outlined to followers. The directive leadership style is favorable in a high-pressure work environment where followers need to achieve challenging targets and goals. Principals must have friendly and approachable relationships with teachers while adopting a directive style of leadership. Healthy and pleasant relationships with teachers form respective and promising work environments. Such auspicious factors create more effective directive leadership.

Northouse [1] describes supportive leadership as friendly and approachable leadership. It emphasizes followers' human needs, well-being (especially the development of pleasant working conditions), equal treatment, respect, and recognition. For this, teachers may give suggestions and ideas to principals to boost the effectiveness of their level of learning and teaching, or they may participate in major policy-making, decision-making, and execution processes. Northouse states that participative leadership empowers shared decision-making, where followers are consulted such that their ideas and suggestions are incorporated into policy-making. To obtain all or some of the required benefits from this leadership style, principals need to encourage teachers' continuous improvement. Furthermore, principals need to have confidence in the competencies of teachers so that they can achieve established challenging goals.

Achievement-oriented leaders let their followers know their expectations. They regularly set clear goals with potential high-performance standards, they trust in the capabilities of their subordinates, and they encourage continued performance improvement [1].

In a nutshell, directive principals generally provide task directions and do not involve teachers in policy-making or major administrative decision-making in schools. Therefore, supportive leadership effectively informs and strengthens directive leadership. Supportive leadership develops favorable work settings that foster high morale and job integrity, feelings of dignity, and more to meet ambitious objectives and goals. Thus, achievement-oriented leadership helps principals to set such objectives and goals, which make teachers active, energetic, and motivated.

The participation of teachers qualifies when they successfully perform their job based on criteria. The participative leadership style amalgamates teachers' expertise and creativity to reach solutions to problems by integrating opinions, ideas, and suggestions. At the same time, principals must somehow provide relief for teachers regarding their slips, negligence, or acts concerned with the nonperformance of businesses or subjects. 


\subsection{Teacher Job Performance Standards}

Teaching and learning are the fundamental ambitions of schools. They provide the foundation of society for youth development. School principals direct and guide teachers to perform their duties to achieve this ultimate ambition. The advancement of teacher efforts is under the specific authority of principal leadership to advocate teaching and learning in a school $[9,10]$.

To strengthen the process, it is crucial to segment teachers' jobs into subcategories of planned goal frameworks, multidimensional job performance constructs, teacher performance factors, competence standards, and KPIs, to manage and measure job performance [11-14], such as teaching planning, classroom organization, monitoring and evaluation, classroom atmosphere and discipline, and teacher leadership [3].

Teaching planning involves drafting lesson plans, class activities, and sets of activities that are carried out while teaching and/or in a classroom [15]. Classroom organization involves arranging the placement of classroom furniture and student seating plans, learning the core material, being aware of the physical circumstances of the classroom, and involving students in learning [16,17]. Student learning assessment methods include exams, tests, homework checking, and all associated judgment procedures, known as monitoring and evaluation [18,19]. Classroom atmosphere and discipline consists of maintaining a safe, healthy, friendly, and fair classroom environment for optimal learning and appropriate and conducive communication $[19,20]$. Student motivation, guidance, mentoring, and positive influence comprise teacher leadership, the fifth construct of job performance [21,22].

\subsection{Principal Leadership and Teacher Job Performance}

Pragmatically, school principals and educational leaders are problem solvers and facilitators [23,24]. Specifically, principals play an especially significant role in promoting teacher job performance at private secondary schools. Hamilton [25] stated that school leaders have a significant effect on school performance. School principals directly or indirectly affect the performance of teachers by means of their style of leadership. Sustaining curricular standards, assessing teaching methods, keeping an eye on student achievements, facilitating teachers, and making arrangements to create an encouraging and achievement-oriented environment to attain challenging goals are some key roles and functions of principalship. Eliminating obstacles and clarifying paths for teachers to perform their job are salient aspects of PGT effectiveness [1] and effective leadership.

Overall, school principals provide support in both academic and administrative spheres through sets of directions and instructions to perform duties and achieve challenging goals, as facilitators and problem solvers. Effective leadership involves providing a set of directions that include action plans; for instance, how and when to implement, motivating followers, setting challenging goals, maintaining friendly relationships, and so on.

Much empirical research has been published on PGT effectiveness to validate the direct effects of the four styles of school principals on teacher job performance. However, these submissions provided only a partial consensus, because they documented teacher job performance holistically. In simple words, earlier studies measured teacher job performance as one component or variable and did not go far enough into the subcategories mentioned above.

For instance, Imhangbe et al. [26] examined the influence of principal leadership styles on teacher job performance in public senior secondary schools in Edo, Nigeria. They conducted a survey of principals and teachers and found a relatively significant influence of democratic leadership style on teacher job performance. Similarly, Atsebeha [3] found a relatively significant influence of supportive leadership on job performance in primary schools in Tigray, Ethiopia. Several other investigations were conducted on this striking phenomenon [27-31].

Notably, all the studies computed teacher job performance KPIs into a single performance factor. Therefore, school leaders, including principals, would be unable to identify problematic aspects of the effect of principal leadership on teacher job performance. Consequently, teachers' efficiency and productivity could decrease due to low job performance. Low performance and productivity would 
lead to a high employee turnover rate, demotivation, and job dissatisfaction [32,33]. Eventually, school aims would not be achieved and overall school performance, especially yield, would decline.

Thus, there is a need to shed light on the effects of PGT principal leadership styles on each domain of teacher job performance, because these effects will provide comprehensive understanding and assistance to school leaders, principals, coordinators, and supervisors to deal with the problematic aspects of various leadership styles. As a result, teachers' job performance and efficiency will improve.

Although previous studies are enlightening, they ignored the perspective of school middle management personnel. Middle management acts as a bridge between senior leadership and forefront staff, and translates the vision of the school $[34,35]$. Additionally, these employees interpret and communicate institutional aims, implement policies, and closely supervise teachers' work [36,37].

Therefore, the school middle management perspective is crucial to take into account. Thus, this research addresses the dearth of knowledge. Likewise, prior studies did not adopt advanced analytical models, e.g., confirmatory factor analysis and structural equation modeling [38-40]. Hence, this research contributes to the current literature.

\subsection{Research Question}

What are the effects of PGT leadership styles on teacher job performance in private secondary schools in Pakistan?

\section{Materials and Methods}

\subsection{Procedure and Participants}

To achieve the study's purpose, 106 urban private co-education secondary schools were deliberately selected for this empirical research in Lahore, Pakistan. In order to successfully achieve the research aims, middle management was chosen as the sample of the study. A total of 292 copies of the questionnaire were given to middle management personnel of private secondary schools under the consent of the head office and school principals during the period of the annual teacher appraisal process of early 2019.

Middle management was limited to vice principals, section heads, and coordinators, who were responsible for supervising teachers and appraising their job performance. Teacher supervisors and appraisers participated in the present study to address the aforementioned research gap regarding the perspective of middle management. Middle management acts as a bridge, liaison, or disseminator; these employees interpret school aims, and goals, and execute management through various objectives (MBOs), and all the required information passes through this channel [34,35].

The 261 questionnaires were returned from the sample of $52 \%$ females and $48 \%$ males. Among the returned copies, 8 were treated as invalid because unengaged responses were found throughout them. The resulting 253 questionnaires represented an effective response rate of $89 \%$.

\subsection{Instrument}

Two instruments, Indvik's [41] path-goal leadership questionnaire (PGTQ) and Atsebeha's [3] teacher job performance questionnaire (TJPQ), were adapted for this study. PGTQ includes 4 styles of PGT leadership: directive, participative, supportive, and achievement-oriented; all constructs include 5 items each. The second instrument was designed to evaluate 5 components of teacher job performance. The original TJPQ contained a total of 34 items: teaching planning ( 7 items), classroom organization (6 items), monitoring and evaluation (7 items), classroom atmosphere and discipline (7 items), and teacher leadership ( 7 items).

As an adaption of the instruments, all statements of PGLQ items were slightly changed from " $\mathrm{I}$ " to "our principal" and "followers" to "teachers," such as "I let followers know what is expected of them" to "Our principal lets the teachers know what is expected of them," with the rest remaining the same. TJPQ items 5, 6, 9, and 13 had amendments to some extent, such as "establishes the guidelines 
and maintains order and discipline in the classroom" to "teachers talk from time to time about positive language usage, ethics, and norms for continued classroom discipline."

The head offices ensured the modifications, overall appearance, and construct validity of the instruments. The head offices had legitimate power, prepared policies, SOPs to perform the tasks, and performance appraisal for teachers. A 4-point Likert scale $(1=$ strongly disagree, $2=$ disagree, $3=$ agree, $4=$ strongly agree) was used to measure the perspective of middle management on the research subject [26,42-44].

\subsection{Statistical Analytic Procedures}

In the present research, Pearson correlation, $t$-test, confirmatory factor analysis (CFA), and the structural equation modeling (SEM) analytic technique were mainly involved in analyzing the middle management perspective. SPSS and Amos were used to conduct the analysis. More to the point, the two models-first-order PGT leadership style (directive, participative, supportive, achievement-oriented) and second-order TJP (teaching planning, classroom organization, monitoring and evaluation, classroom atmosphere and discipline, teacher leadership)—had hierarchical directionality from first-order to second-order.

Thus, CFA was performed for both models, and good model fit measures can be seen in the model fit section. Concerning the ethics, the research supervisor on behalf of the ethical committee of Northeast Normal University, China, approved this research. The university's ethical guidelines were completely considered. Secondly, the study participants took part in the research after providing their own consent. They were permitted to withdraw their consent at any stage of the study before publication. Thirdly, the personal information of participants and other related information were encrypted right after the write-up.

\section{Results}

\subsection{Construct Reliability and Validity}

The original PGT questionnaire had five items each for directive, supportive, participative, and achievement-oriented leadership styles. In the TJP questionnaire, there were seven items for teaching planning, six for classroom organization, and seven each for monitoring and evaluation, classroom atmosphere and discipline, and teacher leadership. Items with chi-square/df over 0.5 were eliminated in confirmatory factor analysis [45]. The remaining items were retained. All PGT items remained the same; however, TJP dropped to five items for teaching planning, four for classroom organization, monitoring and evaluation, classroom atmosphere and discipline, and five for teacher leadership for the flow of constructs.

First, internal consistency and composite reliability were assessed for questionnaire reliability. The internal consistency for each construct was assessed using Cronbach's $\alpha$. Appendix A shows $\alpha$ values in the range of 0.74 to 0.81 for PGTQ styles, and Appendix B shows 0.72 to 0.83 for TJPQ. All values were greater than 0.6 , an acceptable reliability level [46]. Thus, the constructs were found to be reliable [47]. Furthermore, Appendix A shows composite reliability (CR) values ranging from 0.78 to 90 for PGTQ, and Appendix B shows 0.84 to 0.91 for TJPQ, thus surpassing the threshold of 0.7 [45].

Second, construct validity can be obtained from discriminative and convergent validity. Independent t-test can examine the scale of discriminative power. Appendix A reveals t-test values ranging from 51.43 to 86.21 for PGT, and Appendix $B$ reveals values of 50.88 to 82.95 for TJPQ, and they are significant at $\mathrm{p}<0.001$. All items (t-values) above the critical ratio of 3 were discriminative [48]. Moreover, convergent validity was determined using average variance extracted (AVE) and factor loading (FL). Appendices A and B reveal that all AVE values (PGT $=0.71-0.78, \mathrm{TJP}=0.70-0.79$ ) and FL values ( $\mathrm{PGT}=0.66-0.89, \mathrm{TJP}=0.65-0.88$ ) were over the threshold of 0.6 , verifying the construct validity [45]. Thus, the questionnaire's reliability and validity conditions were met. 


\subsection{Descriptive Statistics and Correlations}

Directive leadership style $(M=3.76, S D=0.62)$ had the highest mean value, while participative leadership $(M=2.89, S D=0.72)$ had the lowest mean value among the four principal leadership styles shown in Table 1. Management also assigned higher mean values for achievement-oriented leadership $(M=3.57, S D=0.41)$ than supportive leadership $(M=3.41, S D=0.49)$. As for teacher job performance, the highest mean value was found for monitoring and evaluation $(M=3.34, S D=0.69)$, then classroom atmosphere and discipline $(M=3.28, S D=0.58)$, teacher leadership $(M=3.19, S D=0.37)$, and classroom organization $(M=3.01, S D=0.34)$. All mean values were found to be satisfactory, with a threshold of $M \geq 3[49,50]$.

Table 1. Pearson correlation.

\begin{tabular}{cccccccccc}
\hline Constructs & DLS & PLS & SLS & AoLS & TP & CO & ME & CD & TL \\
\hline DLS & - & & & & & & & & \\
PLS & $0.27^{*}$ & - & & & & & & \\
SLS & $0.45^{* *}$ & $0.26^{*}$ & - & & & & & & \\
AolS & $0.12^{*}$ & 0.35 & $0.60^{*}$ & - & & & & & \\
TP & $0.73^{*}$ & $-0.23^{*}$ & $0.53^{*}$ & $0.48^{*}$ & - & & & \\
CO & $0.59^{*}$ & $-0.29^{*}$ & $0.51^{*}$ & $0.64^{*}$ & -0.27 & - & & \\
ME & $0.52^{*}$ & $0.13^{* *}$ & $0.47^{*}$ & $0.52^{*}$ & $0.32^{*}$ & 0.46 & - & & \\
CD & $0.67^{*}$ & $-0.08^{*}$ & $0.50^{*}$ & $0.44^{*}$ & $0.14^{* *}$ & $-0.21^{* *}$ & $-0.32^{*}$ & - & \\
TL & $0.41^{*}$ & $-0.17^{* *}$ & $0.36^{*}$ & $0.57^{*}$ & 0.29 & $0.34^{*}$ & $0.06^{*}$ & $0.09^{*}$ & - \\
M & 3.76 & 2.89 & 3.41 & 3.57 & 3.25 & 3.01 & 3.34 & 3.28 & 3.19 \\
SD & 0.62 & 0.72 & 0.49 & 0.41 & 0.36 & 0.34 & 0.69 & 0.58 & 0.37
\end{tabular}

${ }^{*} \mathrm{p}<0.01,2$-tailed, ${ }^{* *} \mathrm{p}<0.05$. DLS, directive leadership style; PLS, participative leadership style; SLS, supportive leadership style; AoLS, achievement-oriented leadership style; TP, teaching planning; CO, classroom organization; $\mathrm{ME}$, monitoring and evaluation; $\mathrm{CD}$, classroom atmosphere and discipline; TL, teacher leadership.

As for the associations among constructs, Pearson correlation was calculated, and the four PGT leadership styles as first-order variables were found to be significantly correlated with the five TJP constructs as second-order variables of the research model. Among both orders, directive leadership had a significant and the highest positive correlation with teaching planning $(r=0.73, p<0.01)$, while a significant but the smallest negative correlation was found between participative leadership and classroom atmosphere and discipline $(r=-0.08, p<0.01)$. Moreover, all correlation values of variables were above 0.30 , indicating a moderate level, and above 0.50 largely correlated with the scale [51,52]. However, some insignificant correlations were also found among the items, such as participative with achievement-oriented leadership (see Table 1).

\subsection{Instruments' Fit Indices}

In this research, the overall absolute fit measures for PGTQ were $\chi^{2}=237.76, d f=99, \chi^{2} / d f=2.40$, $p=0.001, \mathrm{RMSEA}=0.06, \mathrm{GFI}=0.92, \mathrm{AGFI}=0.90$, and SRMR $=0.04$. The absolute fit measures for TJPQ were $\chi^{2}=246.59, d f=98, \chi^{2} / d f=2.52, p=0.01, \mathrm{RMSEA}=0.04, \mathrm{GFI}=0.91, \mathrm{AGFI}=0.89$, and SRMR $=0.05$. All indices of the absolute fit measures were considered as good fits, with absolute good fit cutoffs as follows: $\chi^{2} / d f<3$ [45], RMSEA $<0.08$ [53], GFI > 0.85 [54], AGFI > 0.8 [55], and SRMR $<0.08$ [53].

The incremental fit measure indices of PGT styles were CFI $=0.96, \mathrm{IFI}=0.94, \mathrm{NNFI}=0.95$, $\mathrm{NFI}=0.93, \mathrm{RFI}=0.92$, and for TJP constructs were CFI $=0.91, \mathrm{IFI}=0.92, \mathrm{NNFI}=0.94, \mathrm{NFI}=0.92$, and RFI $=0.95$. All indices of incremental fit measures were greater than the threshold 0.90 [47], so they had acceptable model fit goodness. Furthermore, the PGT parsimonious fit indices PNFI = 0.77 and PGFI $=0.67$, and the TJP indices PNFI $=0.69$ and PGFI $=0.78$ can be seen as having a good fit, as they are above 0.5 [56]. All of the above indices of model fit were acceptable for proceeding with the research [45]. 


\subsection{SEM Findings}

The results of SEM analysis (Figure 1) show that the research model (Figure 1) has an acceptable goodness-of-data fit $\left(\chi^{2}=367.25, d f=185, \chi^{2} / d f=1.98, p=0.001\right.$, RMSEA $=0.05$, GFI $=0.90$, AGFI $=0.91$, and SRMR $=0.06, \mathrm{CFI}=0.95, \mathrm{IFI}=0.93, \mathrm{NNFI}=0.92, \mathrm{NFI}=0.94, \mathrm{RFI}=0.90, \mathrm{PNFI}=0.63$, PGFI $=0.61)$.

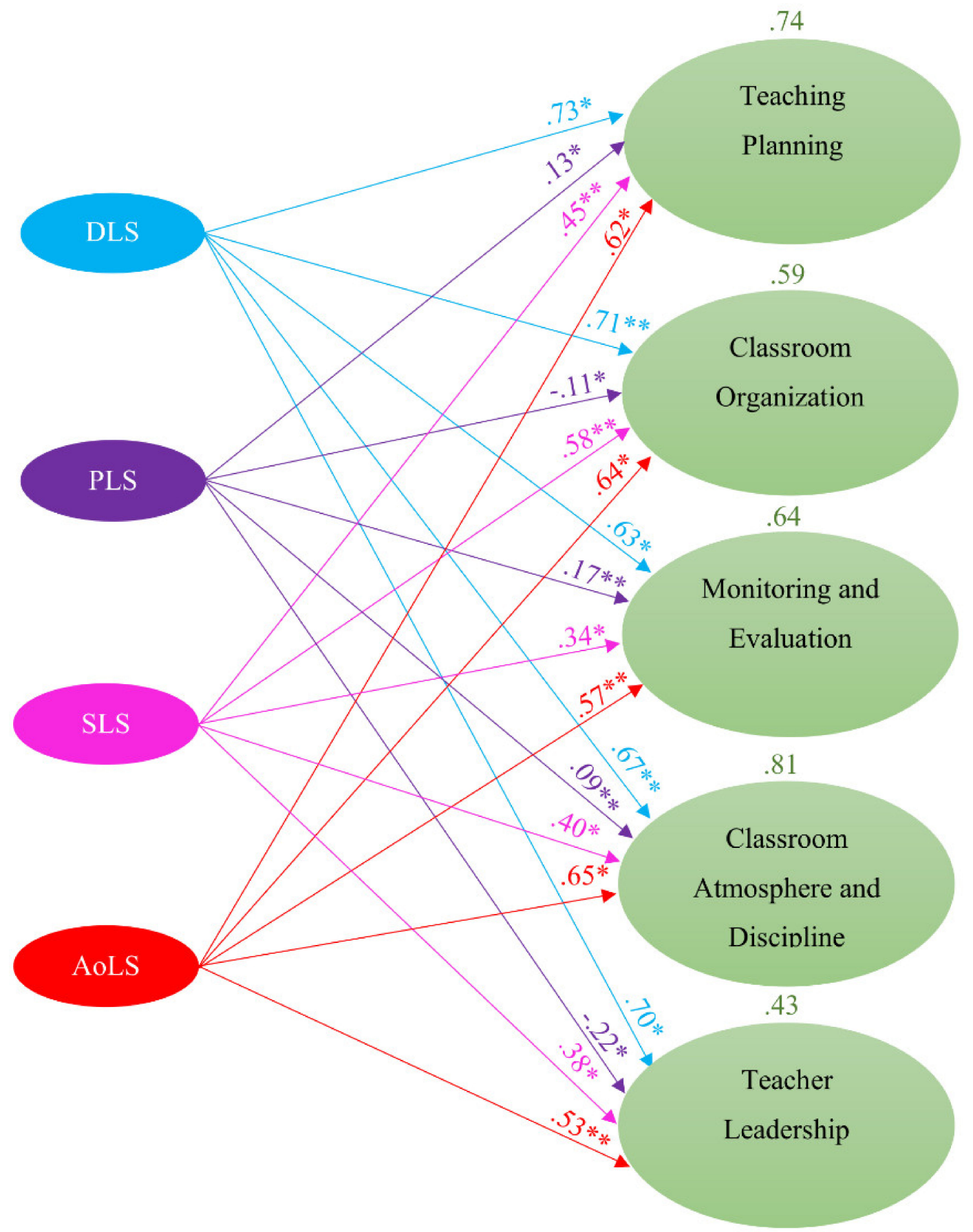

Figure 1. Structural equation modeling (SEM) significant regression paths; ${ }^{*} p<0.01,{ }^{* *} p<0.05$. $\beta$ values are standardized regression coefficients (SRCs), and $n=253$. DLS, directive leadership style; PLS, participative leadership style; SLS, supportive leadership style; AoLS, achievement-oriented leadership style. Model fit indices: $\chi 2=367.25, d f=185, \chi^{2} / d f=1.98, p<0.01$, RMSEA $=0.05$, $\mathrm{GFI}=0.90, \mathrm{AGFI}=0.91$, and SRMR $=0.06, \mathrm{CFI}=0.95, \mathrm{IFI}=0.93, \mathrm{NNFI}=0.92, \mathrm{NFI}=0.94, \mathrm{RFI}=0.90$, PNFI $=0.63$, PGFI $=0.61$. 
The directive leadership style significantly and positively predicted the variance of teaching planning $(\beta=0.73, p<0.01)$, classroom organization $(\beta=0.71, p<0.05)$, monitoring and evaluation $(\beta=0.63, p<0.01)$, classroom atmosphere and discipline $(\beta=0.67, p<0.05)$, and teacher leadership $(\beta=0.70, p<0.01)$. The participative leadership style significantly and positively predicted the variance of teaching planning $(\beta=0.13, p<0.01)$, but negatively predicted the variance of classroom organization $(\beta=-0.11, p<0.01)$, monitoring and evaluation $(\beta=0.17, p<0.05)$, classroom atmosphere and discipline $(\beta=0.09, p<0.05)$, and teacher leadership $(\beta=-0.22, p<0.01)$. The supportive leadership style significantly and positively predicted the variance of teaching planning $(\beta=0.45, p<0.05)$, classroom organization $(\beta=0.58, p<0.05)$, monitoring and evaluation $(\beta=0.34, p<0.01)$, classroom atmosphere and discipline $(\beta=0.40, p<0.01)$, and teacher leadership $(\beta=0.38, p<0.01)$. The achievement-oriented leadership style significantly and positively predicted the variance of teaching planning $(\beta=0.62$, $p<0.01)$, classroom organization $(\beta=0.64, p<0.01)$, monitoring and evaluation $(\beta=0.57, p<0.05)$, classroom atmosphere and discipline $(\beta=0.65, p<0.01)$, and teacher leadership $(\beta=0.53, p<0.05)$.

\section{Discussion}

The application and effects of the leadership styles outlined in the path-goal theory, as articulated in [5], have been found to vary from situation to situation [57], particularly in non-Western developing countries. The present study explored the effects of principal leadership styles on teacher job performance in private secondary schools in Pakistan.

The study results not only show some characteristics of and relationships between leadership styles and job performance but also provide new evidence on the principal leadership styles of path-goal theory as used in a non-Western private education context.

Interestingly, the present study reveals the relatively negative and/or minimal effect of principal participative leadership on teacher job indicators. These findings are in contrast to previous studies, which showed a substantial positive association and effect of principal participative leadership on teacher job performance in general [3,58-61].

Specifically, the participative leadership style had a negative effect on classroom organization and teacher leadership. Meanwhile, it had somewhat a positive effect on teaching planning, monitoring and evaluation, and classroom atmosphere and discipline. Participative leadership had the least effect on teacher job performance in any case, positive or negative. This finding is contrary to the study of Imhangbe, Okecha, and Obozuwa [26], who found a largely positive effect of democratic leadership on teacher job performance in public schools in a non-Asian context. More to the point, participative leadership negatively correlated with teaching planning, classroom organization, classroom atmosphere and discipline, and teacher leadership aside from monitoring and evaluation. Both the correlations and mean value of principal participative leadership style were found to be low at the threshold [49-52].

Possible reasons for this astonishing finding in the present research may be: (a) teachers' job tasks are complex and ambiguous, and their performance goals are quite challenging; (b) principals have a personal obligation to complete tasks; and (c) teachers are required to complete their tasks according to their expected level of performance. Accordingly, teachers are bound to follow dogmatic SOPs circulated by the head office as indicated in the methodology, and principals provide the directions to perform the tasks. The literature supports this viewpoint, while Northouse [1] stated that non-participative directive leadership functions well when subordinates need to follow dogmatic SOPs and tasks are ambiguous. It is the personal obligation of autocratic leaders to complete the tasks $[62,63]$.

Alongside these possible reasons, organizational framework, societal settings, culture, and other contextual factors impact principal leadership [64]. In that sense, the context shapes principal leadership, styles, and standards, which become disparate across nations [65-68]. As noted by Oplatka [69], Western and non-Western contexts are dissimilar, and dissimilarities in the structure of educational systems across countries stem, "at least in part, from the cultural, national, and sociological contexts underpinning education within them" (p. 428). 
Given the tremendous contextual and cultural diversity regarding schooling and education, there is an influence of principals' leadership, behavioral norms, and values that is not similar to that of school leaders in other contexts $[66,67]$. The roles and practices of principal leadership are different in developing countries than in developed countries. Teachers need work clarity and motivation promptly at every level of the job. Non-participative directive leadership efficiently provides instantaneous work clarity and motivation to teachers [70]. This research was conducted in a non-Western developing country where directive leadership could improve teacher performance and professionalism because directive principals advance schools, facilitate teachers, and solve problems.

The present study provides new empirical evidence, as indicated by the SEM results and the correlation matrix, from a non-Western developing country such as Pakistan to support the claim that principals in such countries are "likely to employ autocratic, non-participative, summative evaluation" in contrast to the democratic spirit in the Western context [69].

Miller [24] specified that the principal is a school improvement agent and problem solver who facilitates teachers. As he found in a non-Western context, a principal had "no other choice but to be autocratic and adopt a task-oriented leadership style in order to make sure that students' performance and teachers' professional attitude would improve" (p. 108).

On the one hand, the current study shows the perspective of middle management on the specific effect of leadership PGT styles on teacher job performance within the particular context of private secondary schools by adopting a widely used PGT instrument and the TJP adapted questionnaires. The standpoint of private secondary school middle management was not clear as yet.

For this aspect, this research updates existing literature about the path-goal theory from the viewpoint of secondary school middle management. Middle management is premised on the belief that the principal's abstract language, or strategic language, needs to be translated into operational language [71] that provides support and redirects [34] teachers toward successful job completion and concrete actions [72].

Therefore, it was critically important to consider the middle management perspective. In essence, middle management acts as a bridge between top leadership and frontline staff [35], such as principals and teachers. Middle management is responsible for closely supervising and rating the job performance of teachers, and implements the principal's decisions in the given context.

On the other hand, there is a gap in the knowledge regarding the effects of PGT styles on the subconstructs of teacher job performance: teaching planning, classroom organization, monitoring and evaluation, classroom atmosphere and discipline, and teacher leadership.

The SEM findings of the present study provide new empirical evidence from private secondary schools that directive leadership overall had quite an influence on all constructs of teacher job performance, and it had the largest effect on teaching planning, then classroom organization, teacher leadership, classroom atmosphere and discipline, and monitoring and evaluation.

On the other hand, participative leadership was generally found to have the least effect from the middle management point of view; specifically, it had the least effect on classroom atmosphere and discipline. Achievement-oriented leadership was found to have a larger effect on each construct of teacher job performance than supportive leadership.

Directive leadership had the largest significantly positive effect on teacher performance in general. In the current study, the empirical findings corroborated this claim by providing two possible reasons for the relatively largest effect: (a) achievement-oriented principals consistently set challenging goals for teachers to accomplish, and (b) the supportive style of principals provides support to teachers to overcome problems preventing them from accomplishing their goals. Thus, directive principals provide directions for teachers to finish their jobs effectively. Northouse [1] also supported this claim that directive leaders guide their followers on what to do and how to do it by giving explicit explanations.

The findings also contribute empirically to the present literature about PGT. The findings provide support for the close associations between PGT and teacher job performance constructs. First, middle management considered that directive leadership had the highest positive association 
with all five constructs used to determine teacher job performance, and emphasized the utility of directional leadership.

Second, middle management assigned a relatively low association between participative leadership and the performance constructs. Third, middle management made a higher association between achievement-oriented leadership and the performance constructs, and a moderate association between supportive leadership and teacher job performance constructs, indicating that school principals set quite challenging goals for teachers and provide support to accomplish them $[1,3]$ and for better performance.

Hence, this underpinning choice is linked to the directive attribute of PGT and provides new empirical substantiation to support the claim that challenging goals with supportive work directions by the principal leads teachers to complete their tasks successfully and have better performance.

\section{Limitation and Future Studies}

Primarily, the current investigation is limited to private secondary schools in a developing country in a non-Western Asian context. Therefore, there is an acute need for a manifold conceptualization of the influence of contextual and cultural to validate the possible reasons for the surprising participative leadership outcome of the present study. Secondarily, the current study is limited to the four leadership styles outlined in the path-goal theory and the five constructs of teacher job performance. Including additional variables, leadership styles, and KPIs of teacher job performance, specifically PGT mediating variables of task characteristics and follower (teacher) characteristics, could yield insightful results in future studies.

\section{Conclusions}

The current investigation shows the effects of path-goal theory leadership styles on promoting teacher job performance from the viewpoint of the middle management of private secondary schools. The investigation yielded several encouraging findings. However, it is crucial to note that this study was limited to the private secondary school context in a non-Western developing country. Overall, the findings indicate that PGT styles of principals in private schools are predominantly characterized by directive, achievement-oriented, and supportive leadership, leading teachers to have better performance and complete their jobs successfully, including teaching planning, classroom organization, monitoring and evaluation, classroom atmosphere and discipline, and teacher leadership.

Although PGT styles were found to be effective in the given context, participative leadership was found to be either problematic or unhelpful for all constructs of teacher job performance. Therefore, training for principals on the useful practice of participative leadership functions could be productive.

While considering the effects of and relationships between principals' leadership styles and teachers' job performance, participative leadership should be constructively adopted, and teachers' autonomy and independence should be particularly encouraged to lift their job performance enormously in secondary schools, because, as noted by Oplatka [69] and Hallinger and Kantamara [73], participative leadership promotes a family-like atmosphere in schools, and schools require mutual responsibility and teacher motivation in the long run.

Author Contributions: Conceptualization, A.S. and H.Y.; Data curation, S.A.; Formal analysis, A.S.; Investigation, A.S.; Methodology, S.A.; Project administration, C.R.; Resources, C.R.; Software, A.S.; Supervision, H.-b.Y. and C.R.; Validation, S.A., H.-b.Y. and C.R.; Writing - original draft, A.S. and S.A.; Writing - review \& editing, S.A. and H.-b.Y., A.S. and S.A. contributed equally to the study. All authors have read and agreed to the published version of the manuscript.

Funding: This research received no external funding

Conflicts of Interest: The authors declare no conflict of interest. 
Mean SD FL t-value

\begin{tabular}{|c|c|c|c|c|}
\hline \multicolumn{5}{|c|}{ Directive: $\alpha=0.81, \mathrm{CR}=0.90, \mathrm{AVE}=0.72$} \\
\hline $\begin{array}{l}\text { Our principal let teachers know what is expected } \\
\text { of them. }\end{array}$ & 4.19 & 0.63 & 0.77 & 78.84 \\
\hline $\begin{array}{l}\text { Our principal informs teachers about what needs to } \\
\text { be done and how it needs to be done. }\end{array}$ & 4.74 & 0.78 & 0.85 & 83.54 \\
\hline $\begin{array}{l}\text { Our principal asks teachers to follow standard rules } \\
\text { and regulations. }\end{array}$ & 4.18 & 0.85 & 0.69 & 71.49 \\
\hline $\begin{array}{l}\text { Our principal explains the level of performance } \\
\text { that is expected of teachers. }\end{array}$ & 3.99 & 0.86 & 0.85 & 83.67 \\
\hline $\begin{array}{l}\text { Our principal gives vague explanations of what is } \\
\text { expected of teachers on the job. }\end{array}$ & 4.27 & 0.98 & 0.72 & 65.92 \\
\hline \multicolumn{5}{|c|}{ Participative: $\alpha=0.74, \mathrm{CR}=0.78, \mathrm{AVE}=0.71$} \\
\hline $\begin{array}{l}\text { Our principal consults with teachers when facing a } \\
\text { problem. }\end{array}$ & 3.65 & 0.77 & 0.81 & 77.88 \\
\hline $\begin{array}{l}\text { Our principal listens receptively to teachers' ideas } \\
\text { and suggestions. }\end{array}$ & 4.33 & 0.86 & 0.82 & 51.43 \\
\hline Our principal acts without consulting the teachers. & 3.89 & 0.85 & 0.72 & 86.21 \\
\hline $\begin{array}{l}\text { Our principal asks for suggestions from teachers } \\
\text { concerning how to carry out assignments. }\end{array}$ & 3.78 & 0.94 & 0.81 & 69.49 \\
\hline $\begin{array}{l}\text { Our principal asks teachers for suggestions on what } \\
\text { assignments should be made. }\end{array}$ & 4.76 & 0.83 & 0.89 & 81.34 \\
\hline \multicolumn{5}{|c|}{ Supportive: $\alpha=0.76, \mathrm{CR}=0.85, \mathrm{AVE}=0.74$} \\
\hline $\begin{array}{l}\text { Our principal maintains a friendly working } \\
\text { relationship with teachers. }\end{array}$ & 4.82 & 0.79 & 0.74 & 60.78 \\
\hline $\begin{array}{l}\text { Our principal does little things to make it pleasant } \\
\text { to be a member of the group. }\end{array}$ & 4.01 & 0.82 & 0.74 & 63.54 \\
\hline $\begin{array}{l}\text { Our principal says things that hurt teachers' } \\
\text { personal feelings. }\end{array}$ & 3.79 & 0.87 & 0.66 & 59.32 \\
\hline $\begin{array}{l}\text { Our principal helps teachers overcome problems } \\
\text { that stop them from carrying out their tasks. }\end{array}$ & 4.45 & 0.78 & 0.85 & 79.64 \\
\hline $\begin{array}{l}\text { Our principal behaves in a manner that is } \\
\text { thoughtful of teachers' personal needs. }\end{array}$ & 4.45 & 0.83 & 0.72 & 76.22 \\
\hline \multicolumn{5}{|c|}{ Achievement-oriented: $\alpha=0.79, \mathrm{CR}=0.84, \mathrm{AVE}=0.78$} \\
\hline $\begin{array}{l}\text { Our principal let teachers know that I expect them } \\
\text { to perform at their highest level. }\end{array}$ & 4.75 & 0.85 & 0.79 & 81.54 \\
\hline $\begin{array}{l}\text { Our principal sets goals for teachers' performance } \\
\text { that are quite challenging. }\end{array}$ & 4.40 & 0.76 & 0.89 & 76.23 \\
\hline $\begin{array}{l}\text { Our principal encourages continual improvement } \\
\text { in teachers' performance. }\end{array}$ & 4.44 & 0.76 & 0.84 & 76.83 \\
\hline $\begin{array}{l}\text { Our principal shows that I have doubts about } \\
\text { teachers' ability to meet most objectives. }\end{array}$ & 4.46 & 0.82 & 0.78 & 81.83 \\
\hline $\begin{array}{l}\text { Our principal consistently sets challenging goals } \\
\text { for teachers to attain. }\end{array}$ & 4.42 & 0.87 & 0.81 & 73.37 \\
\hline
\end{tabular}

Figure A1. Internal consistency and composite reliability of PGTQ. 
Appendix B

\begin{tabular}{|c|c|c|c|c|}
\hline & Mean & SD & FL & $t$-value \\
\hline \multicolumn{5}{|c|}{ Teaching Planning: $\alpha=0.78, \mathrm{CR}=0.91, \mathrm{AVE}=0.75$} \\
\hline Teachers prepare well for lessons. & 4.28 & 0.36 & 0.78 & 67.74 \\
\hline $\begin{array}{l}\text { Teachers teach at the level of their learners' } \\
\text { competence and understanding. }\end{array}$ & 3.89 & 0.84 & 0.74 & 74.64 \\
\hline The use of teaching media is well planned. & 4.78 & 0.73 & 0.68 & 82.95 \\
\hline $\begin{array}{l}\text { Teachers provide the right opportunities for } \\
\text { learners to become competent learners. }\end{array}$ & 4.89 & 0.34 & 0.81 & 74.50 \\
\hline Teachers plan effectively to engage learners in & 4.38 & 0.68 & 0.83 & 50.88 \\
\hline
\end{tabular}
their classes.

Classroom Organization: $\alpha=0.82, \mathrm{CR}=0.86, \mathrm{AVE}=0.70$

$\begin{array}{lllll}\text { Teachers organize their assessment according to } & 3.78 & 0.68 & 0.88 & 72.56\end{array}$ the school assessment policy.

$\begin{array}{lllll}\text { Seating arrangements are organized according to } & 4.24 & 0.93 & 0.73 & 78.51\end{array}$ the purpose of the lesson.

$\begin{array}{lllll}\text { Assessment of learners' work is done regularly } & 4.67 & 0.79 & 0.86 & 73.41\end{array}$ according to a planned schedule.

$\begin{array}{lllll}\text { Teachers use teaching time effectively. } & 4.27 & 0.63 & 0.72 & 68.39\end{array}$

Monitoring and Evaluation: $\alpha=0.79, \mathrm{CR}=0.88, \mathrm{AVE}=0.76$

$\begin{array}{lllll}\text { The workbooks of learners are regularly marked. } & 4.87 & 0.69 & 0.82 & 81.31\end{array}$

$\begin{array}{lllll}\text { The workbooks of learners are regularly signed by } & 4.56 & 0.38 & 0.71 & 69.40\end{array}$

both teachers and parents.

$\begin{array}{llllll}\text { Teachers keep a record of marks obtained by } & 3.87 & 0.91 & 0.84 & 62.56\end{array}$

learners and monitor their progress carefully.

$\begin{array}{lllll}\text { Teachers check school attendance of learners and } & 4.59 & 0.74 & 0.69 & 75.34\end{array}$

assist that no learner falls behind.

Classroom Atmosphere and Discipline: $\alpha=0.83, \mathrm{CR}=0.85, \mathrm{AVE}=0.79$,

$\begin{array}{lllll}\text { Teachers manage their classes in a disciplined way. } & 4.64 & 0.48 & 0.83 & 76.81\end{array}$

$\begin{array}{lllll}\text { Classrooms are clean and appropriately decorated. } & 4.18 & 0.63 & 0.76 & 78.23\end{array}$

$\begin{array}{llllll}\text { Teachers communicate in an appropriate way. } & 4.24 & 0.76 & 0.80 & 68.93\end{array}$

$\begin{array}{lllllll}\text { Teachers create a non-threatening classroom } & 3.81 & 0.46 & 0.67 & 60.99\end{array}$

atmosphere conducive to optimal learning.

Teacher Leadership: $\alpha=0.72, \mathrm{CR}=0.84, \mathrm{AVE}=0.73$,

$\begin{array}{lllll}\text { Teachers have a positive influence on learners. } & 4.53 & 0.59 & 0.84 & 72.65\end{array}$

$\begin{array}{lllll}\text { Teachers know and support the vision and mission } & 4.38 & 0.80 & 0.65 & 63.84\end{array}$

of the school.

$\begin{array}{lllll}\text { Teachers motivate learners to learn. } & 3.90 & 0.65 & 0.81 & 79.14\end{array}$

$\begin{array}{llllll}\text { Teachers utilize learner leaders in their classroom } & 4.87 & 0.77 & 0.87 & 80.59\end{array}$

management.

$\begin{array}{llllll}\text { Teachers model values that promote a healthy } & 4.14 & 0.69 & 0.70 & 53.83\end{array}$ classroom culture. 


\section{References}

1. Northouse, P.G. Leadership: Theory and Practice; Sage Publications: Thousand Oaks, CA, USA, 2018.

2. Isaac, R.G.; Zerbe, W.J.; Pitt, D.C. Leadership and motivation: The effective application of expectancy theory. J. Manag. Issues 2001, 13, 212-226.

3. Atsebeha, A.T. Principals' Leadership Styles and Their Effects on Teachers' Performance in the Tigray Region of Ethiopia.; University of South Africa: Pretoria, South Africa, 2016.

4. Evans, M.G. The effects of supervisory behavior on the path-goal relationship. Organ. Behav. Hum. Perform. 1970, 5, 277-298. [CrossRef]

5. House, R.J. A path goal theory of leader effectiveness. Adm. Sci. Q. 1971, 16, 321-339. [CrossRef]

6. House, R.J.; Dessler, G. The Path-Goal Theory of Leadership: Some Post Hocand a Priori Tests. Contingency Approachesto Leadership; Southern Illinois University Press: Carbondale, IL, USA, 1974; pp. $29-55$.

7. House, R.J.; Mitchell, R.R. Path-goal theory of leadership. J. Contemp. Bus. 1974, 3, 81-97.

8. House, R.J. Path-goal theory of leadership: Lessons, legacy, and a reformulated theory. Leadersh. Q. 1996, 7 , 323-352. [CrossRef]

9. Bolman, L.G.; Deal, T.E. Reframing the Path to School leAdership: A Guide for Teachers and Principals; Corwin Press: Thousand Oaks, CA, USA, 2018.

10. Hoerr, T.R. The Art of School Leadership; ASCD: Alexandria, VA, USA, 2005.

11. Ishak, M.I.M.; Suhaida, M.S.; Yuzainee, M.Y. Performance measurement indicators for academic staff in Malaysia private higher education institutions: A case study in UNITEN. In Proceedings of the PMA Conference, Otago, New Zealand, 14-17 April 2019.

12. Parmenter, D. Key Performance Indicators: Developing, Implementing, and Using Winning KPIs; John Wiley \& Sons: Hoboken, NJ, USA, 2015.

13. Lockett, J. Effective Performance Management: A Strategic Guide to Getting the Best from People; Kogan Page: London, UK, 1992.

14. Armstrong, M.; Taylor, S. Armstrong's Handbook of Human Resource Management Practice; Kogan Page Publishers: London, UK, 2014.

15. Savage, J. Lesson Planning: Key concepts and skills for Teachers; Routledge: Abingdon, UK, 2014.

16. Stronge, J.H. Qualities of Effective Teachers; ASCD: Alexandria, VA, USA, 2018.

17. Unger, M.S. Organized Teacher, Happy Classroom: A Lesson Plan for Managing Your Time, Space and Materials; F+ W Media, Inc.: Ohio, USA, 2011.

18. Brookhart, S.M. Formative Assessment Strategies for Every Classroom: An ASCD Action Tool; ASCD: Alexandria, VA, USA, 2010.

19. Glas, C.; Scheerens, J.; Thomas, S.M. Educational Evaluation, Assessment and Monitoring: A Systematic Approach; Taylor \& Francis: New York, NY, USA, 2006.

20. Bandstra, A. Beyond Control: Heart-Centered Classroom Climate and Discipline; BookBaby: Washington, DC, USA, 2016.

21. Farr, S. Teaching as Leadership: The Highly Effective Teacher's Guide to Closing the Achievement Gap; John Wiley \& Sons: Hoboken, NJ, USA, 2010.

22. Dalton, J.; Boyd, J. I Teach: A Guide to Inspiring Classroom Leadership; Heinemann: Portsmouth, NH, USA, 1992.

23. Williams-Boyd, P. Educational Leadership: A Reference Handbook; ABC-CLIO: Santa Barbara, CA, USA, 2002.

24. Miller, P. Cultures of Educational Leadership: Global and Intercultural Perspectives; Springer: Berlin, Germany, 2016.

25. Hamilton, E. Assessing the Relationship of Principals' Leadership Styles on Teacher Satisfaction and Teacher Turnover. Ph.D. Thesis, Northcentral University, San Diego, CA, USA, 2016.

26. Imhangbe, O.S.; Okecha, R.E.; Obozuwa, J. Principals' leadership styles and teachers' job performance: Evidence from Edo State, Nigeria. Educ. Manag. Adm. Leadersh. 2018, 47, 909-924. [CrossRef]

27. Wachira, F.M.; Gitumu, M.; Mbugua, Z. Effect of Principals' Leadership Styles on Teachers' Job Performance in Public Secondary Schools in Kieni West Sub-County. IJHSSI 2017, 6, 72-86.

28. Somech, A. Directive versus participative leadership: Two complementary approaches to managing school effectiveness. Educ. Adm. Q. 2005, 41,777-800. [CrossRef]

29. Okoji, O.O. Relationship between secondary school principals' leadership style and teachers' job performance in selected rural communities of Ondo State, Nigeria. Ann. Modern Educ. 2016, 8, 27-36. 
30. Mwangi, W.J. Effects of leadership styles on teachers' job performance and satisfaction: A case of public secondary schools in Nakuru County, Kenya. Master's Thesis, Kenyatta University, Nairobi, Kenya, 2013.

31. Machumu, H.J.; Kaitila, M.M. Influence of leadership styles on teachers' job satisfaction: A case of selected primary schools in songea and morogoro districts, Tanzania. Int. J. Educ. Adm. Policy Stud. 2014, 6, 53-61.

32. Aziri, B. Job satisfaction: A literature review. Manag. Res. Pract. 2011, 3, 77-86.

33. Vangel,K. Employee Responses to Job Dissatisfaction. 2011, pp. 1-17. Available online: https://digitalcommons. uri.edu/cgi/viewcontent.cgi?article=1030\&context=lrc_paper_series (accessed on 22 December 2019).

34. Stephen, P.; Robbins, C.; Mary, A.; DE Cenzo, D.A. Fundamentals of Management; Pearson: London, UK, 2019.

35. Robbins, S.P.; Coulter, M. Management, 13rd ed.; Pearson India: Bengaluru, India, 2017.

36. Bennett, N.; Newton, W.; Wise, C.; Woods, P.; Economou, A. The Role and Purpose of Middle Leaders in Schools; National College for School Leadership (NCSL): London, UK, 2003.

37. Brown, M.; Rutherford, D. A re-appraisal of the role of the head of department in UK secondary schools. J. Educ. Adm. 1999, 37, 229-242. [CrossRef]

38. Brown, T.A. Confirmatory Factor Analysis for Applied Research; Guilford Publications: New York, NY, USA, 2014.

39. Khine, M.S. Application of Structural Equation Modeling in Educational Research and Practice; Springer: Berlin, Germany, 2013; Volume 7.

40. Marsh, H.W.; Muthén, B.; Asparouhov, T.; Lüdtke, O.; Robitzsch, A.; Morin, A.J.S.; Trautwein, U. Exploratory structural equation modeling, integrating CFA and EFA: Application to students' evaluations of university teaching. Struct. Equ. Model. Multidiscip. J. 2009, 16, 439-476. [CrossRef]

41. Indvik, J. A Path-Goal Theory Investigation of Superior-Subordinate Relationships. Ph.D. Thesis, University of Wisconsin-Madison, Madison, WI, USA, 1985.

42. Likert, R. A technique for the measurement of attitudes. Arch. Psychol. 1932, 22, 55.

43. Yin, H.; Lu, G.; Wang, W. Unmasking the teaching quality of higher education: Students' course experience and approaches to learning in China. Assess. Eval. High. Educ. 2014, 39, 949-970. [CrossRef]

44. Lee, J.C.-k.; Zhang, Z.; Yin, H. A multilevel analysis of the impact of a professional learning community, faculty trust in colleagues and collective efficacy on teacher commitment to students. Teach. Teach. Educ. 2011, 27, 820-830. [CrossRef]

45. Hair, J.; Black, W.; Babin, B.; Anderson, R. Multivariate Data Analysis, 7th ed.; Prentice Hall: Upper Saddle River, NJ, USA, 2010.

46. Hancock, G.R.; Mueller, R.O. Structural Equation Modeling: A Second Course; Iap: NC, USA, 2013.

47. Byrne, B.M. Structural Equation Modeling with AMOS: Basic Concepts, Applications, and Programming; Routledge: New York, NY, USA, 2016.

48. Green, S.B.; Salkind, N.J. Using SPSS for Windows and Macintosh, Books a la Carte; Pearson: London, UK, 2016.

49. Ali, M.M. Associations Between High School Students' Perceptions of Mathematics Classroom Learning Environment and their Academic Achievements and Attitudes in Puntland State, Somalia; MA, Northeast Normal University: Changchun, China, 2019.

50. Appiah, D. Senior High School Students' Attitude Towards Mathematics and Perception of their Mathematics Classroom Learning Environment. M.Phil. University of Education: Winneba, Ghana, 2016.

51. Cohen, J. A power primer. Psychol. Bull. 1992, 112, 155. [CrossRef]

52. Cohen, J. Statistical Power Analysis for the Behavioral Sciences; Routledge: New York, NY, USA, 2013.

53. Hu, L.-t.; Bentler, P.M. Cutoff criteria for fit indexes in covariance structure analysis: Conventional criteria versus new alternatives. Struct. Equ. Model. Multidiscip. J. 1999, 6, 1-55. [CrossRef]

54. Kline, R.B. Principles and Practice of Structural Equation Modeling; Guilford Publications: New York, NY, USA, 2015.

55. MacCallum, R.C.; Hong, S. Power analysis in covariance structure modeling using GFI and AGFI. Multivar. Behav. Res. 1997, 32, 193-210. [CrossRef]

56. Mulaik, S.A.; James, L.R.; Van Alstine, J.; Bennett, N.; Lind, S.; Stilwell, C.D. Evaluation of goodness-of-fit indices for structural equation models. Psychol. Bull. 1989, 105, 430. [CrossRef]

57. Smith, A.J. Implementing Core Values in the High-Tech Industry; Walden University: Minneapolis, MN, USA, 2011.

58. Adeyemi, T.O. Principals leadership styles and teachers job performance in senior secondary schools in Ondo State, Nigeria. Int. J. Educ. Adm. Policy Stud. 2010, 2, 83-91. 
59. Omeke Faith, C.; Onah Kenneth, A. The influence of principals' leadership styles on secondary school teachers' job satisfaction. J. Educ. Soc. Res. 2012, 2, 46.

60. Basit, A.; Sebastian, V.; Hassan, Z. Impact of leadership style on employee performance (A Case study on a private organization in Malaysia). Int. J. Account. Bus. Manag. 2017, 5, 2289-4519.

61. Ozuruoke, A.A.; Ordu, P.; Abdulkarim, M. Leadership style and business educators' job performance in senior secondary schools in a changing environment. J. Educ. Soc. Res. 2011, 1, 149-155.

62. Euwema, M.C.; Wendt, H.; Van Emmerik, H. Leadership styles and group organizational citizenship behavior across cultures. J. Organ. Behav. Int. J. Ind. Occup. Organ. Psychol. Behav. 2007, 28, 1035-1057. [CrossRef]

63. Maloş, R. The most important leadership theories. Ann Eftimie Murgu Univ Resita Fascicle II Econ. Stud. 1, 2012; pp. 413-420. Available online: https://web.b.ebscohost.com/abstract?direct=true\&profile= ehost $\&$ scope $=$ site $\&$ authtype $=$ crawler $\&$ jrnl $=15840972 \& A N=92535234 \& \mathrm{~h}=\mathrm{WjXgPe} \% 2 \mathrm{bZAEtItEhVAJ} \%$ 2fOPIDfqJy5xRBoLMa8BkB\%2f\%2bHujH\%2fMeLFvWaly6OjAEBrpucIkjX56yYFxZAXkXFi\%2fXg\%3d\% $3 \mathrm{~d} \& \mathrm{crl}=\mathrm{c} \&$ resultNs=AdminWebAuth\&resultLocal=ErrCrlNotAuth\&crlhashurl=login.aspx $\% 3 \mathrm{fdirect} \%$ 3dtrue\%26profile\%3dehost \%26scope\%3dsite\%26authtype\%3dcrawler\%26jrnl\%3d15840972\%26AN\% 3d92535234 (accessed on 15 October 2019).

64. Walker, A.; Hu, R.; Qian, H. Principal leadership in China: An initial review. Sch. Eff. Sch. Improv. 2012, 23, 369-399. [CrossRef]

65. Smulyan, L. Balancing Acts: Women Principals at Work; SUNY Press: Albany, NY, USA, 2000.

66. Heck, R. Leadership and culture. Conceptual and methodological issues in comparing models across cultural settings. J. Educ. Adm. 1996, 34, 74-97. [CrossRef]

67. Dimmock, C.; Walker, A. Comparative educational administration: Developing a cross-cultural conceptual framework. Educ. Adm. Q. 1998, 34, 558-595. [CrossRef]

68. Lassibille, G.; Navarro Gómez, L. Organisation and efficiency of education systems: Some empirical findings. Comp. Educ. 2000, 36, 7-19. [CrossRef]

69. Oplatka, I. The principalship in developing countries: Context, characteristics and reality. Comp. Educ. 2004, 40, 427-448. [CrossRef]

70. Malik, S.Z.; Saleem, M.; Naeem, R. Effect of leadership styles on organizational citizenship behaviour in employees of telecom sector in Pakistan. Pak. Econ. Soc. Rev. 2016, 54, 385-406.

71. Barnes, J.; Bessant, J.; Dunne, N.; Morris, M. Developing manufacturing competitiveness within South African industry: The role of middle management. Technovation 2001, 21, 293-309. [CrossRef]

72. Uyterhoeven, H. General managers in the middle. Harv. Bus. Rev. 1989, 67, 136-145. [PubMed]

73. Hallinger, P.; Kantamara, P. Educational change in Thailand: Opening a window onto leadership as a cultural process. Sch. Leadersh. Manag. 2000, 20, 189-205. [CrossRef] 